\title{
THE NEW CATERING REPERTOIRE
}

Volume II Aide-Mémoire du Restaurateur et Sommelier 
Also by H. L. Cracknell and G. Nobis

The New Catering Repertoire

Volume I: Aide-Mémoire du Chef

MASTERING RESTAURANT SERVICE PRACTICAL PROFESSIONAL GASTRONOMY

PRACTICAL PROFESSIONAL CATERING

(with R. J. Kaufmann) 


\title{
The New Catering Repertoire
}

\section{Volume II \\ Aide-Mémoire du Restaurateur et Sommelier}

\author{
H. L. CRACKNELL, FHCIMA, ACF \\ and \\ G. NOBIS, BA (Hons), MSc., MHCIMA
}


All rights reserved. No reproduction, copy or transmission of this publication may be made without written permission.

No paragraph of this publication may be reproduced, copied or transmitted save with written permission or in accordance with the provision of the Copyright, Designs and Patents Act 1988, or under the terms of any licence permitting limited copying issued by the Copyright Licensing Agency, 33-4 Alfred Place, London WC1E 7DP.

Any person who does any unauthorised act in relation to this publication may be liable to criminal prosecution and civil claims for damages.

First published 1990

Published by MACMILLAN EDUCATION LTD

Houndmills, Basingstoke, Hampshire RG21 2XS and London

Companies and representatives throughout the world

Typeset and illustrated by

TecSet Ltd., Wallington, Surrey

British Library Cataloguing in Publication Data Cracknell, H. L. (Harry Louis), 1916The new catering repertoire.

Vol. 2. Aide-mémoire du restaurateur et sommelier.

I. Title II. Nobis, G.

642'.6'0941

ISBN 978-0-333-43485-7

ISBN 978-1-349-21007-7 (eBook)

DOI 10.1007/978-1-349-21007-7 


\section{CONTENTS}

List of Illustrations and Maps

xiv

List of Tables

Foreword by Silvano Giraldin

xvii

Acknowledgements

Introduction

xviii

xix

\section{THE WAITING STAFF HANDBOOK}

1 Service Procedures

Restaurant functional lay-out $\quad 3$

The lay-up of dining tables

2 Rules for Food and Beverage Service 15

Restaurant presentation, reception and etiquette $\quad 15$

$\begin{array}{ll}\text { Receiving customers } & 15\end{array}$

Presenting the menu $\quad 16$

Taking the order $\quad 16$

Recording the order $\quad 17$

Dealing with customers' bills $\quad 19$

Dealing with guests on departure $\quad 20$

Rules of service $\quad 22$

Carrying trays and dishes $\quad 22$

Service sequence $\quad 24$

General rules of serving at the table 26

Using the service spoon and fork $\quad 29$

Maintaining a neat table setting $\quad 30$

Plate clearing $\quad 32$

Crumbing down $\quad 34$

Service of nouvelle cuisine $\quad 34$

Changing tablecloths in the restaurant $\quad 35$

$\begin{array}{ll}\text { Post-service procedures } & 37\end{array}$ 


\section{Contents}

3 Specific Service Procedures $\quad 40$

Service of hors-d'oeuvre $\quad 40$

Service of single hors-d'oeuvre $\quad 41$

Fruits served as hors-d'oeuvre $\quad 56$

Hot hors-d'oeuvre $\quad 58$

Hors-d'oeuvre royale $\quad 59$

Service of soup $\quad 60$

Service of egg dishes $\quad 66$

Service of farinaceous dishes $\quad 69$

Service of fish $\quad 74$

Service of shellfish $\quad 82$

Service of carved joints of meat $\quad 86$

Presentation and service of poultry and game birds $\quad 92$

Service of vegetables with main courses 101

Service of salads $\quad 104$

$\begin{array}{ll}\text { Service of cheese } & 105\end{array}$

Accompaniments and garnishes 109

Presentation and service of dessert 113

$\begin{array}{ll}\text { Coffee } & 123\end{array}$

4 Menus $\quad 130$

Rules of menu composition $\quad 130$

The matching of food and wine $\quad 134$

5 Restaurant Organisation $\quad 136$

Introduction 136

The distinction between a dining-room and a restaurant 137

Methods of food service 138

$\begin{array}{ll}\text { Breakfast service } & 148\end{array}$

$\begin{array}{lr}\text { Afternoon tea service } & 149\end{array}$

6 Restaurant Equipment 151

Crockery $\quad 151$

Table linen $\quad 152$

Glassware $\quad 154$

Cutlery 154

Special dining-room equipment $\quad 158$

$\begin{array}{ll}\text { Cleaning methods } & 165\end{array}$

Ancillary departments of the restaurant $\quad 169$ 
7 Flambé Work

Fish dishes

Meat dishes

Sweet dishes

Coffees

Safe use of lamps

8 Restaurant Control and Pricing 182

Financial control $\quad 182$

Quality control and the monitoring of customer satisfaction 188 Operational aspects of financial budgeting and control $\quad 188$

9 Restaurant Personnel

Attributes and skills

General responsibilities

The use of uniform

The restaurant brigade

Persomnel management in the restaurant

A specimen job analysis for a restaurant manager

Job descriptions

Organisation of restaurant brigade

10 Banquets, Conferences and Outdoor Catering

Introduction

Banquet service

Conference and convention organisation

Outside catering

11 Eating Habits of Nations

Europe

The Americas

Asia

The Middle East

Africa

Australasia

\section{THE WINE WAITING AND BAR STAFF MANUAL}


Quality 290

Making wine $\quad 290$

Bottling 291

Grapes used for making wine 291

The wines of France $\quad 295$

The wines of Italy $\quad 307$

The wines of Germany 313

The wines of Spain $\quad 317$

The wines of Portugal 321

The wines of Australia 323

The wines of the United States 325

The wines of South Africa $\quad 329$

English wine $\quad 329$

Organic wine $\quad 330$

Other wine-producing countries $\quad 331$

13 The Service of Wine 337

Serving temperatures $\quad 342$

Corky wine $\quad 343$

Decanting wine 343

The service of champagne $\quad 345$

The service of port $\quad 346$

Taste guide to wine $\quad 347$

Alcoholic drink and religious beliefs $\quad 347$

14 Fortified Wines, Spirits, Liqueurs and Aperitifs 350

Fortified wines $\quad 350$

Spirits $\quad 354$

List of spirits $\quad 358$

List of liqueurs $\quad 360$

List of aperitifs $\quad 364$

Alcoholic strength $\quad 366$

Spirit measures $\quad 368$

Adulteration of drink $\quad 368$

15 Cocktails and Mixed Drinks 371

Introduction $\quad 371$

Cocktail bar equipment $\quad 372$

Cocktail formulas $\quad 372$ 
16 Bar and Cellar Operation

Public house bars $\quad 384$

Dispense bar $\quad 384$

Rules of bar service $\quad 386$

Beer, lager and canned beer $\quad 389$

Cider and perry 391

$\begin{array}{ll}\text { Bottled water } & 391\end{array}$

17 Cigars

Introduction $\quad 393$

Presentation and service of cigars $\quad 395$

\section{Appendices}

$A$ : Glossay of restaurant terms and terms for the service of mine

$B: A$ comparative vocabulary of restaurant terms (English, French, Italian, German, Spanish)

$C:$ List of garmishes named after famous people and places

D: How to address people of title

$E:$ Styles of folding table napkins

$F:$ Essential restaurant commodities

$G:$ Vending machines

H: Methods of rendering first aid

$I$ : The law and the restaurateur

7 : Creation of a restaurant atmosphere

$K$ : Vintage lists

$L:$ Average life span of pines

M: The great wines of Bordeaux and Burgundy

$N$ : Shippers of wine - some well-known firms

O: Shippers of port, sherry and champagne - some well-known firms 486

$P$ : Organising a wine tasting

$Q:$ Recognition of bottle shapes

$R$ : How wine is made

$S$ : Stills for making wine and spirits 


\section{LIST OF ILLUSTRATIONS AND MAPS}

\section{Illustrations}

1.1 Table lay-out in straight lines (number of places 96) 4

1.2 Table lay-out on the echelon system (number of places 100) 4

1.3 Table lay-out for a dinner dance (number of places 68) 5

1.4 Table lay-out showing gangways (number of places 71) 5

$\begin{array}{lll}1.5 & \text { Waiter's sideboard } & 7\end{array}$

1.6 Table d'hôte cover $\quad 8$

1.7 À la carte cover $\quad 9$

$\begin{array}{lll}1.8 & \text { A specimen menu } & 10\end{array}$

1.9 Special menu cover 11

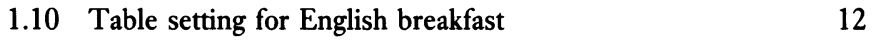

1.11 Tray setting for Continental breakfast 13

1.12 Table setting for afternoon tea 13

2.1 Order of service for a small party 22

2.2 Carrying a tray at shoulder height 23

2.3 Carrying hot plates 24

2.4 Holding a salver correctly 25

2.5 Correct serving position 27

2.6 Correct position for badged plate on table 27

2.7 Placing a cold plate on the table 28

$\begin{array}{lll}2.8 & \text { Serving rolls } & 29\end{array}$

2.9 Use of spoon and fork for service 31

2.10 Using two forks for service 32

2.11 Clearing used plates and cutlery 33

2.12 Clearing debris off plate 33

2.13 Changing tablecloth during service of a meal 36 
2.14 Folding the tablecloth for re-use 38

3.1 Service of globe artichoke $\quad 42$

3.2 Service of asparagus 43

3.3 Service of corn on the cob 44

3.4 Service of foie gras 46

$\begin{array}{lll}3.5 & \text { Service of oysters } & 47\end{array}$

$\begin{array}{lll}3.6 & \text { Service of snails } & 48\end{array}$

$\begin{array}{lll}3.7 & \text { Service of caviar } & 49\end{array}$

3.8 Preparation of seafood cocktail 51

3.9 Service of seafood cocktail $\quad 52$

3.10 Whole smoked trout $\quad 52$

3.11 Smoked mackerel (whole fillet) 53

3.12 Smoked eel (in thin slices) 54

3.13 Service of parma ham and melon $\quad 55$

$\begin{array}{ll}3.14 & \text { Service of avocado pear }\end{array}$

3.15 Service of grapefruit half $\quad 58$

3.16 Service of melon slice $\quad 59$

$\begin{array}{ll}3.17 & \text { Service of soup at the table }\end{array}$

3.18 Service of soup from the guéridon 62

3.19 Service of thick soup from an individual tureen 63

3.20 Service of consommé and clear turtle soup $\quad 64$

3.21 Service of Petite Marmite soup $\quad 65$

$\begin{array}{ll}3.22 & \text { Service of oeufs en cocotte }\end{array}$

$\begin{array}{ll}3.23 & \text { Service of oeufs sur le plat }\end{array}$

3.24 Service of oeufs farcis chimay 68

3.25 Service of omelette $\quad 69$

3.26 Guéridon serving of spaghetti 71

$\begin{array}{ll}3.27 & \text { Service of parmesan cheese } \\ 3.28\end{array}$

$\begin{array}{ll}3.28 & \text { Service of gnocchi in an earthenware dish } \\ 3.29\end{array}$

$\begin{array}{ll}3.29 & \text { A darne of fish }\end{array}$

$\begin{array}{ll}3.30 & \text { A tronçon of fish }\end{array}$

$\begin{array}{ll}3.31 & \text { A paupiette of fish }\end{array}$

$\begin{array}{ll}3.32 & \text { A suprême of fish }\end{array}$

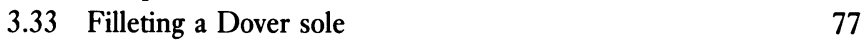

$\begin{array}{lll}3.34 & \text { Filleting a trout } & 79\end{array}$

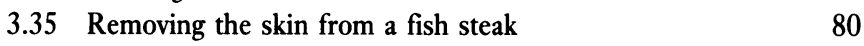

$\begin{array}{ll}3.36 & \text { Portioning a whole poached salmon } \\ 3.37\end{array}$

$\begin{array}{ll}3.37 \text { Cutting a cooked lobster } & 83\end{array}$

3.38 Service of half a cold lobster $\quad 84$ 
3.39 Service of scallops 86

3.40 Carving a boned sirloin of beef (contrefilet) 87

3.41 Carving a leg of lamb 88

3.42 Carving a whole saddle of lamb French-style along the meat grain

3.43 Carving a whole saddle of lamb English style against the meat grain

3.44 Carving roast pork

3.45 Carving best end of veal 90

3.46 Service of sliced meat 91

3.47 Carving a whole chicken at the table 95

$\begin{array}{ll}3.48 \text { Carving a duck } & 97\end{array}$

3.49 Slicing a turkey $\quad 99$

3.50 Presentation and carving of a pheasant 102

3.51 Cheese-board presentation 106

3.52 Service of cheese with a cheese-knife 109

3.53 Preparation of an orange at the table 114

3.54 Preparation of a pineapple at the table 121

3.55 Preparation of strawberries at the table 122

3.56 Service of a gâteau 122

3.57 Service of coffee 126

5.1 Average space requirements and staff-to-customer ratio for different forms of service

5.2 Lay-out of straight-line counter self-service system 139

5.3 Lay-out of the echelon system 140

5.4 Lay-out of the free-flow system 141

5.5 Lay-out of the Carousel system 142

6.1 Crockery items used in restuarants 153

6.2 Shapes of glasses in general use 155

6.3 Designs of cutlery for restaurant use 156

6.4 Special implements used in restaurants 157

6.5 Classic e.p.n.s./plated ware 159

6.6 Larger pieces of equipment used in restaurants 166

8.1 Triplicate checking system pad 185

8.2 Duplicate checking system pad 185

8.3 Cycle of triplicate checking system operation 186

9.1 The restaurant brigade 200

9.2 How to tie a bow tie 203

10.1 Format of a banqueting memorandum 213 
10.2 Seating arrangements for a formal banquet

10.3 Seating arrangements for a less formal banquet

10.4 Table arrangements and the order of service at a wedding (top table)

10.5 Tables lay-out for a buffet reception

10.6 The lay-up for a buffet

10.7 Conference organisation checklist

10.8 Outside catering aide-mémoire

13.1 Opening a wine bottle

13.2 Carrying clean glasses and bottles of wine

13.3 Specimen wine list

13.4 'The Waiter's Friend'

13.5 Opening a bottle of champagne

14.1 Single optic and four-bottle optic. stand

14.2 Fixed pillar stand of optic measures

14.3 Spirit measures on drip tray

14.4 Patterns of flow pourers for inserting into bottles 370

15.1 Cocktail bar equipment

16.1 Signed checks for bar stock control 385

16.2 Glasses for bar service

Al Bin card for cellar control

E1 Folding table napkins: Candle

E2 Folding French napkins

E3 Folding wings napkins

E4 Folding rabbit napkins

E5 Folding rosebud napkins

E6 Folding pointed cap napkins

E7 Folding butler napkins

E8 Folding princess napkins

E9 Folding Arum lily napkins

E10 Folding water lily napkins

E11 Folding cone napkins

E12 Folding cockscomb napkins

E13 Folding mitre napkins

E14 Folding fan napkins

Q1 Common bottle shapes

R1 The wine-making process

S1 A pot still

S2 A patent still (or Coffey still) 
List of Illustrations and Maps

Maps

12.1 The wine-growing areas of France

295

12.2 The wine-growing areas of Italy

308

12.3 The wine-growing areas of Germany

314

12.4 The wine-growing areas of Spain and Portugal

318 


\section{LIST OF TABLES}

3.1 European cheeses

3.2 Appropriate accompaniments and garnishes

3.3 The major coffee-growing countries and types of coffee grown there

3.4 The best-known varieties of special coffees

4.1 Dishes suitable for lunch or dinner

4.2 Matching of food and wine

8.1 Food sales forecast

9.1 Register of staff attendance

9.2 Weekly staff timetable

9.3 Staff duty rota

9.4 Restaurant station allocation

10.1 Alternative uses for a room $500 \mathrm{~m}^{2}$ 


\section{FOREWORD}

For a number of years I, and many of my colleagues working in the front of the house areas, have lamented the absence of a reference book, similar to a chef's repertoire, providing instant information on methods of service. We felt the need for a book that would help to solve the problems encountered by restaurateurs and sometimes barpeople and waiting staff in the course of their duties. It would also codify matters of etiquette, lay down the rules of service and cover all points of restaurant and bar work. In short, a book embodying present day knowledge of food and beverage service.

The need for this kind of book has long been known and, while it is true to say that it has been filled in the past by, for example, the Venetian nobleman Vincenzo Cervio who, in 1571, published his book entitled $I l$ Trinciante which dealt with the art of carving, and others who have written on the many and various aspects of the art of the table, to my knowledge this is the first time that all this information has been brought together in one single text.

I have known the authors of this book for several years and hold their work in great esteem, referring to their manuals without hesitation. They are well known for their academic background as well as for their practical expertise. That knowledge is shown in this encyclopaedic work which I feel sure will be an essential book of reference for all who seek to follow a satisfying career in the hospitality industry.

I believe that by bringing some measure of uniformity to the study of restaurant operation this book will help to enhance the status of my profession and will come to be regarded as a milestone in the continuing development of catering education, both in colleges and in the industry. Its close association with Volume I will surely help towards closer liaison and cooperation on both sides of the hotplate.

SILVANO GIRALDIN

Maitre Restaurateur 


\section{ACKNOWLEDGEMENTS}

The authors and publishers are grateful to Ronn R. Wiegand, Master Sommelier, who publishes the hospitality newsletter Restaurant Wine and is wine columnist for the San Francisco Examiner, for his work in preparing the section on US wines in Chapter 12, and to Brian Stonier, owner of Stonier's Merrick's Vineyard, for preparing the section on Australian wines in Chapter 12. 


\section{INTRODUCTION}

In presenting Volume II of The New Catering Repertoire the authors would like to make the point that they have endeavoured to bring together the corpus of knowledge concerning the theory and practice of food and beverage service as they have evolved through the years, from very early traditions to the present standards of service. That some value can be had from an observance of traditions is evidenced by the remarks of the great chef Escoffier when he wrote: 'The history of the table of a nation is a reflection of the civilisation of that nation.' This book embraces the knowledge of the present-day state of the art of good service as practised in the best establishments everywhere in the world.

Chefs have long had the benefit of a workbook of instructions on the make-up of dishes and now, with this volume, waiters have their own handbook of all the information they need to know and on the understanding of the manifold aspects of service. The many seemingly minor points of etiquette and minutia of bringing food and drink to the consumer are brought to the fore because together they form the basis of the enjoyment of the arts of the table. It should not be thought that some of the details dealt with are now obsolete or no longer of any importance. The expression 'bow in a deferential stance' may appear to be archaic in this egalitarian age but such an instruction is not given merely to perpetuate a dichotomy between master and servant and certainly not to denigrate the status of restaurant and bar staff. But such an instruction does help to maintain a link with worthwhile traditions, some of which have lasted since Roman times and it can still help to emphasise the respect between fellow-beings whether in the role of customer or colleague. The techniques described herein are those in present-day use and it is the authors' fervent wish that this book will assist in setting or maintaining quality standard practices and further enhance the callings of waiter and barperson.

H. L. CRACKNELL

G. NOBIS 